\title{
Deviant Trajectories at the Turning Point between Adolescence and Adulthood
}

\author{
Michel Born and Claire Gabvray
}

This chapter will investigate deviant trajectories in an effort to understand the development of adolescents or adults whose socialization is out of step with the established norms of society. Regardless of whether deviance is defined according to a statistical norm or in terms of the transgression of a coherent group of norms and rules considered to guarantee social order, the deviant is exposed to society's disapproval and reproving looks and, even more specifically, those of the moral entrepreneurs, according to Becker (1985).

Either the transgression remains an occasional act, limited to some behaviours for which society shows a certain tolerance, not endangering the individual's social, cultural and moral integration, or the deviance becomes a way of life, invading social life and relationships over a long period of time.

Research shows that although hyperspecialized deviant careers exist, they are rare. Usually, one observes a diversification, a spiral and an entanglement of the committed acts: thefts and attacks, but also transgressions linked to the sale and consumption of drugs. All of this is done as part of a life out of step with the conventional social world. In their works, Gottfredson and Hirschi (1990), as well as Jessor and Jessor (1977) come to the same conclusion: some common factors explain strictly deviant trajectories and those associated with delinquency. This way of life does not happen overnight; it is built into a developmental process. Every psychological or psychosocial intervention as well as every inquiry or test in the course of a study comes at a specific moment in the subject's personal trajectory, when he/she commits acts which are more or less deviant, and at a different phase of social maladjustment or exclusion.

In order to tackle the theme of drug use and criminality, it is impossible to neglect the construction hidden behind these words, the social, moral or ideological connotations brought about by these social phenomena.

In examining deviant trajectories, we have to question the issue of convergence between criminal careers and drug-user careers during an individual's development. Even if biases are important and recognized as visible, we can refer to a few informative studies of convergences observed among populations of offenders and drug users.

A study in Hamburg (Schwanke, 1989; see Junger-Tas, 1991) shows that, among the drug users identified as such by the police, 20 per cent were responsible for aggravated theft and 33 per cent for burglary. In Stockholm, identified drug users only represent 2 per cent of the male population but were responsible for 45 per cent 
of the known crimes (Sarnecki, 1987). In England, a sample with 300 delinquents revealed that 30 per cent of those responsible for aggravated theft and 60 per cent of burglars were drug users (Parker and Newcombe, 1987). In Belgium, statistics from the Liège Police Department indicated (October 1992) that half of the 24143 registered thefts in 1991 were linked to drug abuse.

Let us look, then, at a few studies about some aspects that do not rely on the identification of drug abuse by police departments themselves (Grapendaal, 1989; see Junger-Tas, 1991). The Netherlands studied the source of incomes of about 150 serious drug users (100 of them under methadone treatment): 40 per cent of their incomes came from delinquency ( 22 per cent from the classical delinquency plus 18 per cent from drug trafficking) and 18 per cent from 'deviant behaviour' (prostitution). Burr (1987) observed that a group of young adults in the urban South London centre all confessed to a past during which they skipped school and were delinquents and also light drug users. Some of them then evolved towards a way of overcoming a heroin addiction but continued to use hashish and alcohol.

As far as trajectories are concerned, Elliott (et al.) (1985) assume from data of the National Youth Survey, a longitudinal study on 1725 subjects between 1976 and 1986 (in six waves), that some category shifts are more frequent than others. It is more frequent (and hence more probable) to stay in the same category as years go by, in other words:

- stay neither multiple drug user nor delinquent,

- stay multiple drug user and delinquent,

- stay either multiple drug user or delinquent.

In addition, it appears that most of the people who start as multi-drug users and as serious delinquents tend to remain multiple drug users but not necessarily serious delinquents. The most stable category is that of multiple drug use: once in this category, it is highly probable for the individual to stay there and to add delinquent ways of behaving.

It seems that these convergences of behaviours are supported by common factors which are seen as similar predicting elements identified in research on drug use and on delinquency. For example, the list of predictors for drug abuse suggested by Kandel (1987) is clearly comparable to the list of predicting elements for delinquency set up by Leitenberg (1987). See Table 6.1.

These convergences are observable in surveys simultaneously studying delinquency and drug abuse variables among identical subjects.

The covariation of delinquent and drug addiction trajectories relies on a great convergence of risk and predicting factors. More than that, we are led to believe that there is a common ground as far as family, relationships and personal characteristics are concerned which will be expressed in a specific way of discovering drugs for some young people or of having 'exploratory' delinquent behaviours for others. Often when these behaviours tend to persist towards the end of adolescence and at the beginning of adulthood, the behaviour convergence will be fully realized: the drug addict commits crimes and the delinquent encounters drugs either in the places where he/she hangs around or in prison.

It is within this developmental perspective that the results presented here must be 
viewed. They are based on a research project done in the department of Psychology of Delinquency and Psychosocial Development at the University of Liège (Born et al., 1997; Gavray 1997). They give a comparative view of the deviant trajectories appearing in a 'run-of-the-mill' population group at the turning point between adolescence and adulthood.

This study concerns the less serious or moderate delinquent career, a reflection of ordinary delinquency and addiction in the general population of which only certain members will be caught and possibly subjected to criminal penalties or even prison.

Table 6.1 List of predictors for drug abuse by Kandel and list of predicting elements for delinquency by Leitenberg

\begin{tabular}{|l|l|}
\hline \multicolumn{1}{|c|}{ Kandel: drug abuse } & \multicolumn{1}{c|}{ Leitenberg: delinquency } \\
\hline alcohol consumption & be a boy \\
belief in the positive value of & live in a disadvantaged area \\
some drugs & experience flimsy and/or rejecting \\
poor relationships with one's parents & family discipline and/or inadequate \\
depressive feelings & supervision \\
being associated with drug users & grow up in a family where dissension \\
desire for independence & and a lack of affection and/or of \\
feeling of psychological malaise & cohesion rule \\
weak expectations & be rejected by one's parents \\
weak school motivation & (and mostly by one's father) \\
biased, tolerant attitude in favour & be a 'difficult', restless, hyperactive, \\
of deviant ways of behaving & 'aggressive'/child experience \\
delinquency & successive failures at school \\
& come from an unemployed 'minority' \\
& have a family or brotherhood with \\
& delinquent activities \\
& have a negative self-image \\
& be in contact with delinquent peers \\
\hline
\end{tabular}

\section{METHOD}

A longitudinal follow-up of a population group at the turning point between adolescence and adulthood can shed light on the dynamics between a deviant trajectory and a trajectory of economic, social, family, normative and cultural integration by youths. The results presented here come from analysis done on data gathered four years apart, from a mixed sample of 139 youths ( 74 girls and 65 boys) who were interviewed for the first time in 1992 when they were between 16 and 21 years old.

This research relies on self-reported delinquency. Despite the fact that this methodology may be the object of some reservations and criticism because of the 


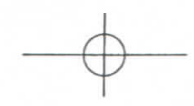

way it takes into account a relatively harmless delinquency and only effectively applies to the cases of individual youths, it seems to be the only one apt to detect the real extent of delinquency. This seems even truer if one uses the longitudinal and comparative viewpoint to try to understand the processes at work in the general population rather than to generate statistics.

Subjects came from an initial mixed sample of 618 youths from Liège between 14 and 21 years old in 1992, a sample comprised according to the framework and criteria of research on self-reported delinquency carried out by the International Self-Reported Delinquency Survey (Born and Gavray, 1994). The sample was representative of the Liège population for that age group (sex, nationality, status student, worker or other status - kind of studies followed or finished, belonging to what type of household or roots). Owing to the desire to study the many aspects of young people's integration, the decision was made in 1996 to recontact as many young people as possible from the original sample, who by then were 21 to 25 years old. Of the 444 subjects corresponding to the age criteria, 139 were found and administered a new questionnaire. The consistency and representativeness of this longitudinal sample's demographic, statutory and behavioural characteristics were ensured. The youths who were questioned again were revealed to be neither more nor less delinquent than in 1992. This subsample did not include very young adolescents in the first round, which could reduce the possibility of bringing to light all the stages of development referred to in the literature and mentioned in the introduction. On the other hand, the follow-up of these persons went beyond the strict limits of adolescence and into adulthood, the period of statutory, professional and demographic transition.

The list of potentially deviant actions over the last 12 months is the standard used by the international study mentioned above. They can be classified into general categories: fraud and offences linked to age and status, theft (shoplifting or purse snatching), violence and aggression against goods or persons, activities linked to drug use, sale and trafficking. Alcohol use has been included in the list of potentially deviant behaviour because it can lead to prejudicial demeanour towards oneself or others. However, sporadic and reasonable drug use during the period being studied did not seem to be a sign of deviance for our reference group.

The desire to observe and classify deviant trajectories required that several artificial variables of the degree of delinquency and its transition be set up. For each wave, one had available the following:

- detailed information according to which the subject had admitted to committing each of the acts considered, over the last 12 months;

- artificial information according to which he/she had committed at least one act on the full list, no matter which one;

- intermediary information about his/her possible participation in the four general categories classified under the key words 'theft, violence, drug, fraud';

- a combination of these kinds of acts (specialization or polymorphism).

Detailed and artificial indicators provided information about the frequency of committing each act or each category of acts.

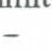


Finally, a score of general seriousness was attributed to each youth for each of the years under consideration. This score was constructed by adding all of the partial scores concerning each act on the list and keeping in mind three elements:

- Has the subject admitted committing this act during the period under consideration?

- How many times has he/she committed this act during this period?

- What is the frequency of committing this act in the entire sample group?

\section{RESULTS}

First wave of investigation: frequency of delinquent and drug related behaviours in adolescence (age 14 to 21 in 1992)

For the total sample of 618 , we mainly found practices which, by their repetitive nature and component elements, were of a minority deviant culture. Thus, we might think of the very high frequency of graffiti. In fact, among the 14 per cent who had drawn graffiti, 21 per cent had done it more than 11 times during the year. Carrying a weapon quite easily becomes a habit, since among the 11 per cent of young people who had done this, 44.3 per cent had done it more than 11 times. Drug taking is also highly repetitive: among the 6.5 per cent who had done it in the previous year, 37.2 per cent had done so more than 11 times.

The other acts for which we observed a high frequency were relatively tolerated practices, such as driving without a licence, fare dodging or truancy from school.

Table 6.2 Frequency of delinquent acts committed during 'last year' in 1992 $(n=618)$

\begin{tabular}{|c|c|c|c|c|c|c|c|c|c|c|c|c|}
\hline \multirow[t]{2}{*}{$\begin{array}{l}\text { Type } \\
\text { of act }\end{array}$} & \multicolumn{2}{|c|}{0 time } & \multicolumn{2}{|c|}{ 1-2 times } & \multicolumn{2}{|c|}{$3-5$ times } & \multicolumn{2}{|c|}{$6-10$ times } & \multicolumn{2}{|c|}{$\begin{array}{l}11-50 \\
\text { times }\end{array}$} & \multicolumn{2}{|c|}{$\begin{array}{l}51 \text { times } \\
\text { or more }\end{array}$} \\
\hline & $\mathrm{n}$ & $\%$ & $\mathrm{n}$ & $\%$ & $\mathrm{n}$ & $\%$ & $\mathrm{n}$ & $\%$ & $\mathrm{n}$ & $\%$ & $\mathrm{n}$ & $\%$ \\
\hline Theft & 462 & 74.2 & 63 & 10.2 & 41 & 6.6 & 16 & 2.6 & 29 & 4.7 & 7 & 1.1 \\
\hline Violence & 450 & 72.8 & 42 & 6.8 & 30 & 4.9 & 26 & 4.2 & 34 & 5.5 & 36 & 5.8 \\
\hline Drug use & 575 & 93.0 & 16 & 2.6 & 5 & 0.8 & 6 & 1.0 & 5 & 0.8 & 11 & 1.8 \\
\hline Cheating & 379 & 61.0 & 68 & 11.0 & 67 & 10.8 & 39 & 6.3 & 47 & 7.6 & 18 & 2.9 \\
\hline
\end{tabular}

Fortunately, Table 6.2 reveals a rather low frequency of criminal acts classified as serious, which are only committed repeatedly by a few subjects already heavily involved in criminal practices (Born, 1983; Le Blanc, 1996). An analysis of correspondence using the Benzecri method (which is based on covariations between contingency tables) carried out on these cases clearly demonstrated the continuum of seriousness and incidence of criminal acts (see Figure 6.1). 

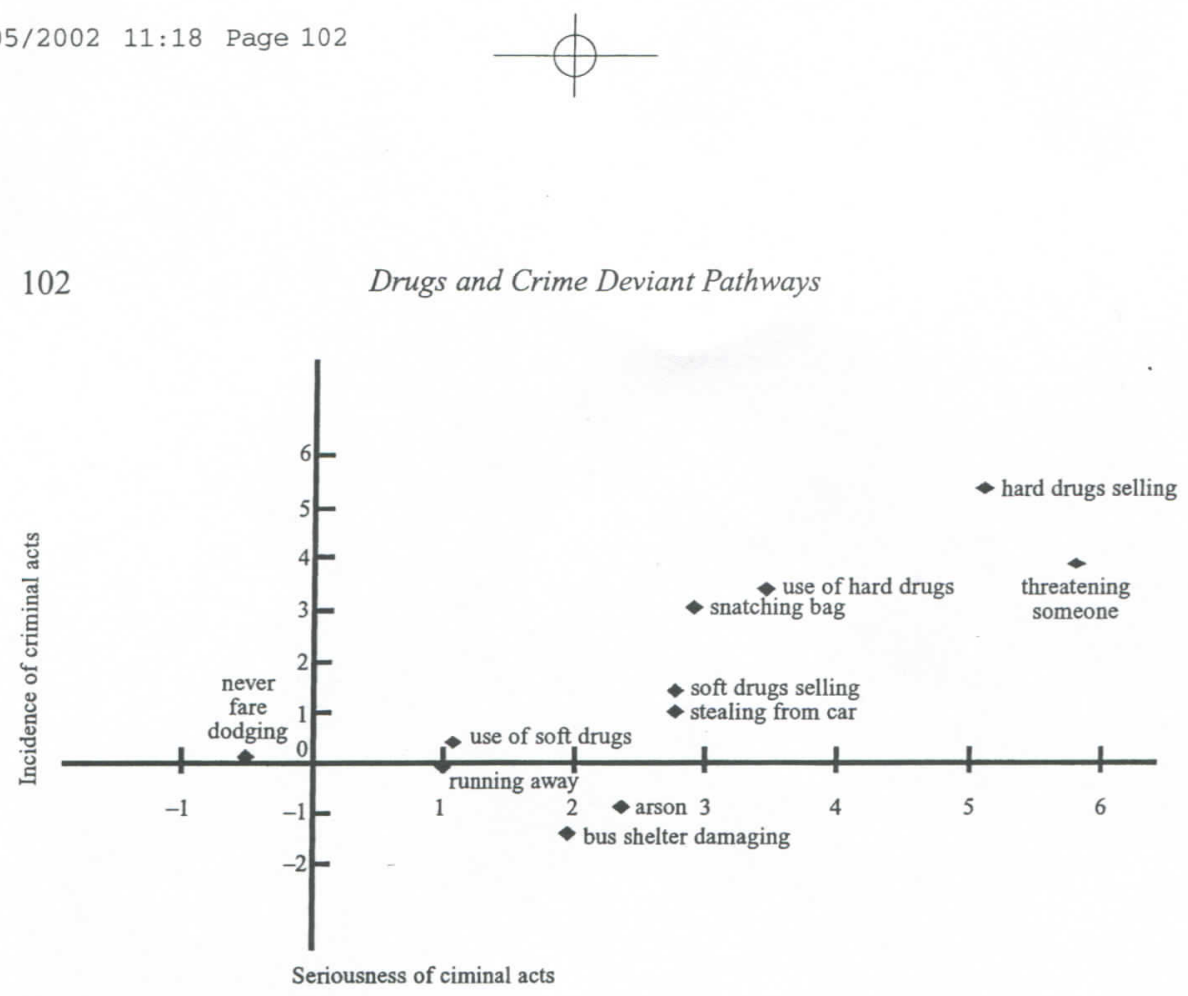

Figure 6.1 Seriousness and incidence of criminal acts

The comparison of replies given by boys and girls to questions about criminality show that wrongdoing is much more common among boys than among girls. The total percentages of young people having committed acts hide the large disparities which exist between young male and female offenders. The more violent, uncommon and risky the act, the greater this disparity becomes. For example, theft with violence, participating in fights or injuring others are more often a phenomenon of small, structured groups (see Table 6.3).

Table 6.3 Comparison of replies given by males and females to questions about criminality

\begin{tabular}{|l|rl|rr|}
\hline Type & \multicolumn{2}{|c|}{ Male } & \multicolumn{2}{|c|}{ Female } \\
& $\mathrm{n}=285$ & $\%$ & $\mathrm{n}=333$ & \multicolumn{1}{c|}{$\%$} \\
\hline Property offences & 102 & 35.8 & 67 & 20.1 \\
Violent offences & 113 & 39.6 & 72 & 21.6 \\
Drug offences & 36 & 12.6 & 15 & 4.5 \\
Other youth-related offences & 145 & 50.9 & 108 & 32.4 \\
Overall prevalence of delinquency & 192 & 67.4 & 155 & 46.5 \\
Without alcohol and problem behaviour & & & & \\
Problem behaviours without alcohol & 110 & 38.6 & 80 & 24.0 \\
\hline
\end{tabular}




\section{Similarities of predicting models for drug use and delinquency}

Using logistic regression, we can identify the best model based on the available variables to predict two types (weak and serious) of drug consumption and thefts when compared with those who do not have such behaviours. Among all the variables tested, only those above the 0.01 level of significance in at least one analysis were kept (see Table 6.4).

Table 6.4 Similarities of predicting models for drug use and delinquency

\begin{tabular}{|c|c|c|c|c|}
\hline \multirow[t]{2}{*}{$\begin{array}{l}\text { Logistic regression } \\
\mathrm{N}=631\end{array}$} & \multicolumn{2}{|c|}{$\begin{array}{c}\text { Drugs } \\
\text { Having taken }\end{array}$} & \multicolumn{2}{|c|}{ Delinquency } \\
\hline & $\begin{array}{l}\text { Cannabis } \\
67 \text { subjects }\end{array}$ & $\begin{array}{c}\text { Heroin, } \\
\text { cocaine } \\
9 \text { subjects }\end{array}$ & $\begin{array}{l}\text { Having committed } \\
\text { a theft in a store } \\
214 \text { subjects }\end{array}$ & $\begin{array}{l}\text { Having committed } \\
\text { a theft in a car } \\
29 \text { subjects }\end{array}$ \\
\hline Sex: boy & $\mathrm{S}$ & & $\mathrm{S}$ & $\mathrm{s}$ \\
\hline Age & $\mathrm{S}$ & & & \\
\hline $\begin{array}{l}\text { Citizenship Belgian } \\
\text { EEC } \\
\text { Non-EEC }\end{array}$ & & & & \\
\hline $\begin{array}{l}\text { Land of origin: } \\
\text { not Belgian }\end{array}$ & & & & \\
\hline $\begin{array}{l}\text { Does not live with } \\
\text { parents }\end{array}$ & $\mathrm{S}$ & $\mathrm{S}$ & $\mathrm{S}$ & \\
\hline $\begin{array}{l}\text { Lives with the mother } \\
\text { alone }\end{array}$ & $\mathrm{S}$ & & & \\
\hline $\begin{array}{l}\text { Lives with the father } \\
\text { alone }\end{array}$ & $\mathrm{S}$ & & & $S$ \\
\hline $\begin{array}{l}\text { Relationships with the } \\
\text { father during childhood }\end{array}$ & & & $\mathrm{s}$ & \\
\hline $\begin{array}{l}\text { Relationships with the } \\
\text { mother during childhood }\end{array}$ & & $\mathrm{s}$ & & \\
\hline $\begin{array}{l}\text { Relationships with the } \\
\text { mother now }\end{array}$ & & & & $\mathrm{s}$ \\
\hline Confide in the mother & & & & \\
\hline $\begin{array}{l}\text { Parents know where } \\
\text { kids are }\end{array}$ & $\mathrm{s}$ & $\mathrm{s}$ & $\mathrm{s}$ & $\mathrm{s}$ \\
\hline $\begin{array}{l}\text { Parents don't know with } \\
\text { whom kids go out }\end{array}$ & & & & $\mathrm{s}$ \\
\hline Stood down a class & & & & $\mathrm{s}$ \\
\hline Do you like school? & $\mathrm{s}$ & & & \\
\hline Small paid jobs & & $\mathrm{S}$ & $\mathrm{S}$ & \\
\hline
\end{tabular}

Note: $\mathrm{S}<.05$ 
The similarities, as well as the divergences, of these factors deserve to be taken into account and contradict Hirschi's theory of social bound by showing that the lack of parental control is the only common factor. This is demonstrated by the fact that the youth does not live with his/her parents and does not inform the parents when going out.

\section{Comparison between the two years of the investigation}

Despite taking into account some 'exploding' practices such as carrying a weapon or buying stolen goods, the data collected during the two rounds of inquiry indicated that the number of offences admitted to between 1992 and 1996 increased significantly (see Table 6.5). The average score for boys as well as for girls doubled between the two years, but the male score was on average five times higher than that of the girls for the two rounds. An increased prevalence was borne out for every type of deviant act except statutory acts (fraud). This is not really surprising because, in essence, this kind of act is closely tied to the judicial, official and social status of the subject (student, young person less than 18 years old forbidden access to certain places or practices). Vandalism and graffiti were equally revealed to be more 'concentrated' in adolescence.

Table 6.5 Prevalence of delinquent acts

\begin{tabular}{|l|r|r|r|r|r|r|}
\hline Type of act & $\begin{array}{r}1992 \\
\mathrm{n}\end{array}$ & $\begin{array}{c}(\mathrm{n}=618) \\
\%\end{array}$ & $\begin{array}{c}1992 \\
\mathrm{n}\end{array}$ & $\begin{array}{c}(\mathrm{n}=139) \\
\%\end{array}$ & $\begin{array}{c}1996 \\
\mathrm{n}\end{array}$ & $\begin{array}{c}(\mathrm{n}=139) \\
\%\end{array}$ \\
\hline Prevalence of thefts & 169 & 27.3 & 36 & 25.9 & 50 & 36.0 \\
Prevalence of violent acts & 185 & 29.9 & 30 & 21.6 & 45 & 32.4 \\
Soft drug use & 49 & 7.9 & 11 & 7.9 & 25 & 18.0 \\
Hard drug use & 6 & 0.9 & - & - & 8 & 5.8 \\
Soft drug sale & 10 & 1.6 & 3 & 2.2 & 4 & 2.9 \\
Hard drug sale & - & - & - & - & 2 & 1.4 \\
Prevalence of acts linked & 51 & 8.2 & 11 & 7.9 & 26 & 18.7 \\
$\quad$ to drugs & & & & & & \\
\hline
\end{tabular}

The same trend towards an increase was borne out in the terms of participation in the number of different kinds of acts, confirming the trend towards polymorphism. Nineteen per cent of the sample's subjects ( 21 per cent of the boys and 16 per cent of the girls) appeared simultaneously in several of the four categories of behaviour in 1992, 33 per cent (43 per cent of the boys but 22 per cent of the girls) in 1996. In fact, the gap between the sexes and between the rounds of inquiry differed according to the type of behaviour. The gap widened when examining acts of violence, that remained the prerogative of the male subjects over the period being studied. 
On the other hand, the gap narrowed concerning statutory acts, theft, the presence during a fight or 'symbolically' damaging goods. Surprisingly, a substantial increase in acts linked to drugs for the boys and a decrease for the girls was observed between the two rounds.

In accordance with the developmental approach, one can ask how the development of delinquency follows another rhythm or logic according to gender. It is interesting to note how the subject's age influences the commission of a delinquent act or certain type of offence. The fact that the sample did not include individuals less than 16 years old in the first round does not allow one to look into the precocious stages of the development of delinquency cited above. The sample was divided into three age categories in 1992: the 16-17 year olds, the 18-19 year olds and the 20-21 year olds.

In fact, age was not shown to play a significant role except in statutory acts in the second round, and this in a way one expected: the closer the subject was to 25 years old in 1996, the more likely that he/she had not committed any 'fraud' during the second year. For the rest, no significant link was established between age and the score of delinquency, the propensity to have presented a specific type of act or a different rate of prevalence, whether examining 1992 or 1996. It was the same for young men and young women. Does one have to abandon the developmental path to understand deviant acts? Or does one have to think in a different way to learn valid lessons on the explicative ability of the latter? In fact, the comparison of tendencies between the two rounds did not make it possible to know to what extent it was the same people who continued to be delinquent from one year to another. It is the same when studying unemployment. The rate may be steady, but that does not mean that the same subjects form the group of unemployed people from one year to another. Only a longitudinal type of investigation may allow us to move forward in an analysis in trajectory or transitional terms.

\section{Links in the seriousness of exhibited deviancy between the first and second rounds}

Based on existing data, a 'rough' typology of transitions can be constructed according to whether a subject has committed a deviant act:

- neither of the two years = no delinquents

- only the first year = desistents

- only the second year = new delinquents

- both in 1992 and 1996 or, more precisely, within the 12 months preceding each round of investigation $=$ persistents. 
Table 6.6 Deviant trajectories according to transitions in/out of delinquency. in relation to specific delinquent acts

\begin{tabular}{|l|c|c|c|c|}
\hline & $\begin{array}{c}\text { Desistents } \\
(\mathrm{n}=12) \\
1992 \\
\%\end{array}$ & $\begin{array}{c}\text { New delinquents } \\
(\mathrm{n}=37) \\
1996 \\
\%\end{array}$ & $\begin{array}{c}\text { Persistents } \\
(\mathrm{n}=51) \\
1992 \\
\%\end{array}$ & $\begin{array}{c}\text { Pesistents } \\
(\mathrm{n}=51) \\
1996 \\
\%\end{array}$ \\
\hline Theft & 66 & 40 & 55 & 69 \\
Aggression & 33 & 38 & 60 & 64 \\
Cheating & 66 & 56 & 55 & 61 \\
Use/traffick of drugs & 0 & 22 & 21 & 35 \\
\hline
\end{tabular}

The analyses show that between the two years that were studied, a majority of the young people persisted in committing at least one delinquent act. A minority showed up only in the first round with at least one behaviour on the list (see Table 6.6).

What does the very significant correlation between the score of seriousness of deviancy in 1992 and 1996 mean $(r=0.42)(p=0.001)$ ? Does it attest to persistence, or even getting out-of-control in the delinquency process? This hypothesis seems to be confirmed by the strong correlations that also exist concerning the number of acts and the number of types of acts between 1992 and 1996. When examining how the correlations show up according to age group, only the inter-year correlations concerning acts of violence and drugs were significant in the three age groups. They indicated the getting-out-of-control and the persistence of delinquency. Among the subjects having committed at least one delinquent act, a strong involvement in drugrelated incidents in 1992 proved to be predictive of the same kind of act in 1996 (r $=0.46, \mathrm{p}<0.001)$, no matter which age group was considered. This is also confirmed by the fact that the mean score of delinquent activity of those who are drug uses are higher than those who are non-drug uses (see Table 6.7).

Table 6.7 Mean score of delinquency in 1996 according to drug use in 1992

\begin{tabular}{|l|c|}
\hline & $\begin{array}{c}\text { Mean score of delinquency } \\
\text { in 1996 }\end{array}$ \\
\hline Non-drug users in 1992 & 0.48 \\
Drug users in 1992 & 2.69 \\
\hline
\end{tabular}

Note: $\mathrm{P}=0.0001$

As expected, if the analysis of correlations between the same kind of acts shown in the first and second rounds is refined by gender, there is still no significant correlation concerning youthful frauds, either for boys or for girls. On the contrary, 
in the two subgroups, a precocious tendency towards aggression has proved to be a good predictor of the anchoring of this behaviour in adulthood. As for the correlation between the years concerning committed theft, it is true only for the girls. The number of drug-related incidents in 1996 did not remain significantly correlated to the situation in 1992, as was the case with the boys. The complexity of results taken from statistical analysis is noticeable here.

What about the significant correlations between the different types of acts for a specific year and between the years by gender? In general, the 1992/1996 behaviour of boys is more consistent than that of the girls. Only the boys demonstrate a significant and systematic correlation between the number of incidents linked to drug use in 1992 and the behaviour connected to each of the four main categories of deviant acts exhibited in 1996. For them, participation in drug-related incidents show up in the adoption of a marginal lifestyle with statutory acts and 'wanton' defacing at the start of adulthood. No matter which age group is considered, the overall masculine delinquency score in the second round proves to depend very significantly on the degree of involvement in drug-related incidents and violence. On the other hand in the female group, even if it concerns a rare phenomenon, the only significant correlation observed is that between a serious involvement in theft in 1992 and violent demonstrations four years later.

After we take into account the customary precautions with respect to the small scope of the sample, we can reasonably believe in the worth of such a model that makes a link between the gravity of the deviance of 1996 each time according to the occupied status and the involvement in a drug-related act $(\mathrm{p}=0.0001$ when we take into account the consumption in 1992 and in 1996). See Table 6.8.

Table 6.8 Mean score of deviance in 1996 according to the combination of two factors (social and professional trajectories and possible drug consumption in 1996)

\begin{tabular}{|l|c|c|c|}
\hline $\begin{array}{l}\text { Social and } \\
\text { professional trajectory }\end{array}$ & $\begin{array}{c}\text { Drug consumption } \\
\text { in } 1996\end{array}$ & Number of subjects & $\begin{array}{c}\text { Gravity and } \\
\text { deviance score }\end{array}$ \\
\hline Student & no & 31 & 0.20 \\
\hline Working person & yos & 10 & 0.84 \\
\hline Unemployed who has & yes & 48 & 0.22 \\
already worked & yes & 19 & 3.17 \\
\hline Unemployed who has & no & 7 & 0.50 \\
never worked & yes & 14 & 5.20 \\
\hline
\end{tabular}

These results are startling since they show an increase in the number of young drug users between the two surveyed years. This evolution goes far beyond the sole consumption of psychoactive substances and also refers to the needs, practices and 
group norms among the young users. Our analyses shed light on the links between deviance and difficulties in becoming involved or stable in active life. Yet these links are probably not unilateral. In a dynamic vision of delinquent life, one's behaviour also influences the position and resources of youth in the future.

Early involvement in acts linked to drugs is significantly important for the young adult's later delinquent life. Particular attention will have to be devoted to drugrelated practices, including the consumption of soft drugs. Such behaviour increases the probability not only of multiplying participation in all other types of prohibited acts, but also of the confirmation of the delinquent course beyond adolescence. Persistent deviant persons have clearly started a delinquent spiral, inasmuch as they accumulate the type and number of acts and tend proportionally to be more exposed to victimization than other groups.

\section{Comparison between persistent delinquent non-users and persistent delinquent users}

When only taking into account the 51 youths who confessed a persistent delinquent way of behaving between 1992 and 1996, 18 admitted having used drugs during the 12 months before the 1996 survey (see Table 6.9). The delinquent drug users (DU) were characterized by a greater likelihood of having committed thefts or violent acts in 1996, but there was no difference as far as statutory acts were concerned: a majority of youth, from both groups committed them.

Table 6.9 Characteristics of consumption among delinquent users

\begin{tabular}{|l|l|l|}
\hline 18 DU Subjects & Soft drugs $(\mathrm{n}=17)$ & Hard drugs $(\mathrm{n}=7)$ \\
\hline Usage & $\begin{array}{l}1 / 3 \text { occasional users } \\
1 / 3 \text { regular users }\end{array}$ & $\begin{array}{l}\text { One used heroin } \\
\text { Six used cocaine } \\
\end{array}$ \\
& $\begin{array}{l}\text { Five used amphetamines } \\
\text { Five used ecstasy } \\
\text { Sale }\end{array}$ & Five used cocktails \\
& 4 & 2 \\
\hline
\end{tabular}

The DU group is characterized - and this comes as no surprise - by the multiplicity of forms the produced delinquency takes (one third of the subjects showed a combination of all types of deviant acts) whereas the delinquent non-user (DNU) group committed acts which were generally more selective and specialized (more than the half of the group committed only one type of act). Hence it seems logical that the delinquency score of the DU group turned out to be on average three times higher than the DNU score in 1992 and seven times higher in 1996. This means that 
the users' group includes a greater number of delinquents in the two waves. It is even more interesting to observe that, whereas the average DNU delinquency rate remained stable between 1992 and 1996, the DU rate tripled. The use of psychoactive substances seems to play a role in the dynamics and notably in the early use (before the 1992 survey). The DU group is also more likely to be victimised, most often the object of violent acts (more often having been given a beating $(p=0.03)$ ). This group eventually becomes more frequently involved in such things as carrying and using a weapon, either in self-defence or to intimidate others.

Table 6.10 Characteristics of delinquency among delinquent non-users and delinquent users

\begin{tabular}{|l|c|c|}
\hline & DNU (\%) & DU (\%) \\
\hline $\begin{array}{l}\text { More than one theft during } \\
\text { the last 12 months }\end{array}$ & 54 & 94 \\
A violent act & 51 & 77 \\
Against goods & 18 & 44 \\
Against persons & 24 & 61 \\
\hline
\end{tabular}

It is interesting to observe that 17 of the 18 subjects from the DU group who were users in 1996 showed a high level of depression in 1992, compared with 19 among 33 DNU subjects who were non-users at the end. Yet we did not notice in 1992 any significant relationship within the group between drug taking and simultaneous signs of a breakdown, whereas more DNU than DU subjects subjects ended up very depressed in 1996.

We might evoke the hypothesis that low psychological resources coupled with drug use during adolescence is fertile ground for the birth of a serious delinquent process taking various forms, such as increased use of psychoactive substances. This process is not necessarily accompanied by increased symptoms of depression but might allow them to be maintained at a manageable level.

While we did not find any significant difference with respect to age (or indeed sex) between the deviant groups (DU and DNU), we nevertheless found social and familyspecific points within both groups. The DU group turned out to come from a more privileged social and cultural background and more often had Belgian citizenship (see Table 6.12). In fact, 25 per cent of the DNU youth (compared to 11 per cent of the DU group) thought their parents did not have any social and professional plans for them in the future (a sign of a lack of parental involvement but also maybe of a lack of social or cultural resources which might allow them to advise or orient their child efficiently).

Youths from the DU group described their original social group as being higher than that of youths in the other group. The former were twice as likely (66 per cent of the DU versus 33 per cent of the DNU) to believe they will have a higher social position than their parents. In fact, this optimism might not be grounded since it relies on their parents' higher financial support. In the first place, 66 per cent of the DU (36

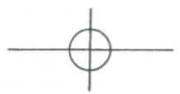


per cent of the DNU) regularly received money from their family. In the second place, 42 per cent of the DU (only 7 per cent of the DNU) were sometimes financially helped by their parents (to settle problems when they arose). Besides this support, we also found greater possibilities of making money among the users: 51 per cent of the DNU and 22 per cent of the DU had official professional incomes; 27 per cent of the DNU and 44 per cent of the DU said they worked or were active on the black market. Moreover, 83 per cent of the DU ( 36 per cent of the DNU) confessed to taking part in the illegal trafficking of stolen goods (as buyer or retailer).The habitual delinquent users in 1996 had a very close relationship with money and desired goods.

Table 6.11 Nationality and work situation of the father among DNU and DU

\begin{tabular}{|l|c|c|}
\hline & DNU (\%) & DU (\%) \\
\hline Belgian citizenship & 54 & 83 \\
Father who works & 67 & 90 \\
\hline
\end{tabular}

It is interesting that, whereas the DNU group had a rather realistic image of themselves and their know-how, users were in two extreme situations. This group (more than the DNU group) simultaneously and proportionally had young people who accorded themselves no know-how and young people who granted themselves maximum know-how. This might be seen as an indicator of a lack of clear-mindedness for these young people with respect to the tools they possess and build upon.

The original social advantages are indeed shaken by lesser quality objective professional and social integration perspectives among the delinquent users. Indeed, we find the smallest number of students among them (16 per cent of the DU, 42 per cent of the DNU) but the highest number of persons without a specific status: neither workers nor students ( 50 per cent of the DU, 27 per cent of the DNU). There was also a higher proportion of young people who stood down a class (33 per cent of the DU and 18 per cent of the DNU), the highest number of youths who say they experienced serious difficulties at school (42 per cent of the DU compared with 27 per cent of the DNU) and the smallest number of young people who attended remedial classes or extra day or evening school lessons. Whether or not they were still attending school, the highest level of current or completed study was not as good. Half of the young DU did not go beyond a vocational diploma; such is the case for 18 per cent of the DNU. It therefore comes as no surprise that working users had a lower qualified job compared with others. As a follow-up, 34 per cent of the DU (15 per cent of the DNU) said that schoolteachers never understand their students.

As far as family is concerned, the DU group were more likely to express the possibility of their parents' strong disappointment with respect to their professional and training prospects. 27 per cent of them thought their parents were very disappointed by their child compared to only 6 per cent in the other group. Hence relationships with the parents were very different in the two groups, whereas we did not find any significant difference as far as parental control was concerned for the two groups in either wave of the survey. 
The difference did not show up in the level of satisfaction with the affection received from parents or on their openness to dialogue, but on the degree of distance established by the young person. Eighty-four per cent of the DU and 66 per cent of the DNU said they never confided in their father $(p=0.06)$, whereas 36 per cent of the DNU (only 16 per cent of the DU) said they never confided in their mother. The strictly affective relationship with the mother was also deeper in this last group.

Could the slightly higher number of young users who live with their mother alone leading to the youth's feeling of responsibility or remorse be the sole explanation for these results? At least it appears that the young DU were in fact more numerous in comparison to the DNU in wishing to follow family values similar to those of their parents.

As far as values and opinions are concerned, these young users operate in a short term, materialistic and individualistic way. Although 27 per cent of the DU ( 9 per cent of DNU) proclaimed that it is important to defend one's ideas, they did not look inward for guidance about their lives or to make up their mind. Eleven per cent of the DU (27 per cent of the DNU) insisted on the importance of spirituality and thought, and inner beauty; 44 per cent of the DU (63 per cent of the DNU) said that it is important to give meaning to one's life. Getting into opposition mattered, but this has to happen with the maintaining of the security brought about by the parents' liberalities. A greater proportion of users were looking for a way of having fun than the non-users ( 56 per cent versus 21 per cent) and increasing a casual love life (33 per cent versus 6 per cent). Yet the DU were less satisfied than the DNU with their love and affective life ( 6 per cent versus 28 per cent). Not as many wanted to find the great love affair ( 1 per cent versus 33 per cent). On the contrary, they lived surrounded by friends. They would often go out on the town with 'buddies' (almost every day for 78 per cent of the DU and 35 per cent of the DNU and regularly for 69 per cent of the DU versus 33 per cent of the DNU.

The values of 'work' and 'profession' were more widely criticized by the users' group, with 27 per cent of the DU and 58 per cent of the DNU saying that work is very important: they distanced themselves more from the ideas defended by their parents' generation on that matter. Hence users were temporarily or progressively involved in a subculture in conflict or breaking with the societal culture still recognized by the majority as progressive and leading to a higher life standing. Compared to the other group, they were less keen on the virtues of perseverance, respecting societal rules and honesty. What they really valued was being imaginative, curious and being a leader. Thirty-three per cent of the DU and 9 per cent of the DNU said they worked according to their own wishes, saw themselves as being impulsive but tended to think more about the pain an action could cause their family before or after the fact. This confirms the close relationship to family we noted earlier. Compared to the DNU (6 per cent of the DU versus 23 per cent of the DNU), they were less likely to think that stealing from a rich person is a serious crime.

Such an experience and the conception of life which accompany it do not necessarily lead to a happier life, without any problems or tension, since the psychoactive substance users were significantly more likely to say they regularly have black thoughts ( 28 per cent versus 3 per cent of the DNU), are unable to make a decision (16 per cent versus 3 per cent) and are very easily irritated (34 per cent versus 9 per cent). 
Internal and social functioning can thus help reinforce the delinquent and psychoactive substance-using trajectory, which can then induce changes in personality, attitudes and values. The dangers of a social and social-professional disintegration are real. As for the family, nothing tends to indicate that the parents will go on being long-term partners during these evolutions. The familial financial help can turn out to be the best, but also the worst, thing.

\section{Results of the explanatory model used by the PROBIT analysis}

The analysis deals with the combination of early factors (adolescence in 1992) and those during adulthood (in 1996) explaining the probability that a persistent delinquent $(\mathrm{N}=51$ subjects) will end up being a drug user: 18 are in such a situation, 33 are not (see Table 6.12 and 6.13).

Table 6.12 Regression of 1992 factors on the use of drugs among persistent delinquents

\begin{tabular}{|l|l|c|}
\hline Factors 1992 & Intercept $\mathrm{P}=0.005$ \\
\hline Be very depressed in 1992 & $\mathrm{P}=0.007$ & Estim. 1.91 \\
See one's future in a positive, optimistic way & $\mathrm{P}=0.007$ & Estim. 1.30 \\
$\begin{array}{l}\text { Take part in the trafficking of stolen goods, in } \\
\text { schemes (small services on the black market) }\end{array}$ & $\mathrm{P}=0.004$ & Estim. 1.39 \\
\hline
\end{tabular}

Table 6.13 Regression of $\mathbf{1 9 9 6}$ factors on the use of drugs among persistent delinquents

\begin{tabular}{|l|l|l|}
\hline Factors 1996 & Intercept $\mathrm{P}=0.02$ \\
\hline Have conventional values and attitudes & $\mathrm{P}=0.02$ & Estim. -1.12 \\
Have a job or study & $\mathrm{P}=0.04$ & Estim. -1.10 \\
Confide in one's father & $\mathrm{P}=0.01$ & Estim. -1.35 \\
Confide in one's mother & $\mathrm{P}=0.04$ & Estim. 1.05 \\
Behave according to one's instinct and wishes & $\mathrm{P}=0.04$ & Estim. 0.89 \\
\hline
\end{tabular}

According to these analyses, young people who add drug use to their persistent delinquency trajectory are characterized by the following elements. During their adolescence (between 16 and 21 years old) they felt ill-at-ease and, got involved in small trafficking networks which gave a slightly more optimistic self-image as regards their future. Yet we do not find any relationship to self-assessed parental relationships at the time, to the affirmed values or to particular personality traits. During adulthood (between 21 and 25 years old), these same persistent delinquent

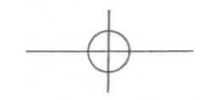


drug users tend to show clear signs of social and professional disintegration and seem to enter a counter-conventional subculture. They move and progress according to their own wish. The distance from the father has widened whereas the mother is approached or accepted as an ally.

\section{CONCLUSION}

Research tends to show that the predicting elements for persistent delinquency and drug use are similar, since the lack of family ties, school drifting, marginalizing of values and association with deviant peers are always found. In our survey, we have tried to understand which effect drug use could have on the adult trajectory of those who are persistent delinquents. The results are very clear on that level, since delinquency worsens if drug use was present during adolescence. Moreover, we have tried to understand the differences between a persistent delinquent drug user and those who are persistent delinquents but who do not use drugs.

Young adults who add drug use to their persistent delinquency have experienced during adolescence a more intense psychological malaise, have used a whole range of schemes (more or less illegal jobs) which allowed them to believe that their future might offer them various possibilities despite their lack of involvement in school. By the time they were adults, the resources turned out to be insufficient (notably because of relationship problems with the father, who in many cases had stopped providing any financial help, crucial for their continued use). Their sole possibility was then to turn to their living on the fringe and fully participate in this culture. Thus drug use and delinquency tend to be the everyday life conditions of these young adults who have not yet been in touch with the judicial system but who are already strongly involved in a delinquent and drug use trajectory which might continue for many years.

\section{REFERENCES}

Becker, H.S. (1985), Outsiders, Paris: A.M. Métailié.

Born, M. and Gavray, C. (1994), 'Self-reported Delinquency in Liège', in J. Junger-Tas, G.J. Terlouw and M.W. Klein (eds), Delinquent Behavior among Young People in the Western World, Amsterdam: Kuwler Publications, pp.131-55.

Born, M. (1983), Jeunes déviants ou délinquants juvéniles?, Liège: Mardaga.

Born, M., Chevalier, V. and Humblet, I. (1997), 'Resilience, desistance and delinquent career of adolescent offenders', Journal of Adolescence, 20, 679-94.

Burr, A. (1987), 'Chasing the dragon: Heroin misuse, delinquency and crime in the context of South London culture', British Journal of Criminology, 27 (4).

Elliott, D.S., Huizinga, D. and Ageton, S.S. (1985), Explaining Delinquency and Drug Use, Beverly Hills: Sage Publications.

Elliott, D.S., Huizinga, D. and Menard, S. (ed.) (1989), Multiple Problem Youth, Delinquency, Substance Use and Mental Health Problems, New York: Springer-Verlag.

Gavray, C. (1997), 'Trajectoire déviante à la lisière entre adolescence et âge adulte', Déviance et Société, 21 (3), 273-88.

Gottfredson, M. and Hirschi, T. (1990), A General Theory of Crime. Stanford, CA: Stanford University Press. 
Hammersley, R., Forsyth, A. and Lavelle, T. (1990), 'The criminality of new drug users in Glasgow', British Journal of Addiction, 85 (12), 1583-94.

Jessor, R. and Jessor, S.L. (1977), Problem Behavior and Psychosocial Development: A Longitudinal Study of Youth, New York: Academic Press.

Junger-Tas, J. (1991), 'Jeunes adultes délinquants et politique criminelle', Dixième colloque criminologique, Conseil de l'Europe, Strasbourg.

Kandel, D.B. (1987), Longitudinal Research on Drug Use, New York: John Wiley.

Le Blanc, M. (1996), 'Changing patterns in the perpetration of offenses over time: Trajectories from early adolescence to the early 30's', Studies on Crime and Crime Prevention, 5, (151), 65 .

Leitenberg H. (1987), 'Primary prevention on delinquency', in J.D. Burchard and S.N. Burchard (eds), Prevention of Delinquent Behavior, Newburg Park, CA: Sage Publications.

Parker, H. and Newcombe, R. (1987) 'Heroin use and acquisitive crime in an English community', The British Journal of Sociology, 38, (3), 331-50.

Sarnecki, J. (1987), 'The Connection between Drug Abuse and Crime', Conseil de 1'Europe, Conférence sur la réduction de l'insécurité urbaine, novembre. 